Revista de la red interuniversitaria de estudios sobre las literaturas rioplatenses contemporáneas en Francia

19 | 2018

La rebelión de los hijos: el judaísmo en la literatura latinoamericana contemporánea entre tradición y asimilación

\title{
El judaísmo en la obra de Sergio Chejfec: escribir desde una cultura ausente
}

Benoît Coquil

\section{OpenEdition}

\section{Journals}

Edición electrónica

URL: http://journals.openedition.org/lirico/6486

DOI: $10.4000 /$ lirico.6486

ISSN: 2262-8339

Editor

Réseau interuniversitaire d'étude des littératures contemporaines du Río de la Plata

Referencia electrónica

Benoît Coquil, «El judaísmo en la obra de Sergio Chejfec: escribir desde una cultura ausente »,

Cuadernos LIRICO [En línea], 19 | 2018, Puesto en línea el 20 enero 2019, consultado el 01 mayo 2019

URL : http://journals.openedition.org/lirico/6486 ; DOI : 10.4000/lirico.6486

Este documento fue generado automáticamente el 1 mayo 2019.

\section{cc)}

Cuadernos LIRICO está distribuido bajo una Licencia Creative Commons Atribución-NoComercial-

SinDerivar 4.0 Internacional. 


\title{
El judaísmo en la obra de Sergio Chejfec: escribir desde una cultura ausente
}

\author{
Benoît Coquil
}

¿Qué tengo de común con los judíos? Apenas tengo algo en común conmigo mismo.

Franz Kafka

\section{Una transmisión fallida}

1 "El primer libro es el que se piensa y se escribe desde la intemperie más absoluta", reconocía el escritor Sergio Chejfec en $2015^{1}$. El primer libro no tiene parámetros respecto a la cuales definirse, es una creación ex nihilo, una pura tentativa o incluso un electrón libre que escapa a los criterios de autoridad que envuelven el universo de todo autor consagrado. Pero sin duda esta sensación de "intemperie" franqueada por Chejfec a la hora de escribir Lenta biografía tiene sus particularidades: la primera novela de Chejfec contiene/lleva la marca de una interrogación profunda en cuanto a los medios y fines de la escritura, en cuanto al contenido y los destinatarios de la escritura (auto)biográfica y ficcional, a la identidad de quien escribe así como de sus antepasados. Cabe subrayar que en Lenta biografía la investigación de los orígenes, judíos en este caso, condiciona el conocimiento autobiográfico del autor y por consiguiente la posibilidad de la escritura. Lenta biografía evoca una transmisión memorial y cultural fallida, un legado imposible, que implica para el escritor una identidad judía ausente. La posición del escritor es la del hijo frente al padre y a la familia judía, el hijo que no hereda la cultura judía y que entonces investiga esta falta de transmisión.

En Lenta biografía, Chejfec usa la primera persona para construir un relato de sus orígenes: cuenta el exilio de su padre judío polaco hasta Argentina para escapar del nazismo así como su propia infancia pasada en Buenos Aires entre el idish paterno y el castellano escolar. En la primera página del libro, Chejfec evoca la voluntad de su padre de contar su 
propia historia, un deseo rápidamente imposibilitado por la necesidad de contar previamente la vida de sus padres, abuelos, bisabuelos, etc., haciendo que la tarea se vuelva infinita:

Enseguida abandonó su idea: me dijo, con otras palabras, que para comenzar como correspondería por su nacimiento e infancia debía remitirse a sus padres, y luego a sus abuelos -a las vidas de todos ellos-, y que aquélla era una empresa de lo más trabajosa y pesada; que él carecía de la suficiente "paciencia" para hacerlo. ${ }^{2}$

El padre le delega entonces al hijo la tarea biográfica. El texto que sigue este incipit se revela sumamente perturbador para quien esperara una biografía lineal y cronológica, compuesta por hechos concretos y una lógica de causalidad. En realidad el relato, desplegado de modo iterativo, cíclico, y constantemente ralentizado por repetidos incisos, no brinda al lector ni nombre, ni fecha, ni lugar. Además, la tarea de la anamnesis, de la recolección del pasado que parecería anunciar el título se asocia con la de la imaginación, de la ficción, y también es un constante objeto de reflexión y de cuestionamiento. El tema central del relato es menos el pasado en sí, en el sentido de un mero contenido biográfico, que las posibilidades y modalidades de su resurgencia por la memoria.

Cabe agregar que la transmisión del contenido biográfico se halla mediada por el hecho de que procede de una memoria al cuadrado, por así decirlo: no es el padre el que cuenta su historia y el trauma sufrido durante la Shoah y el exilio sino el hijo, a partir de los recuerdos del padre, y sobre todo a partir de la ausencia de esos recuerdos. El relato del pasado traumático lo produce entonces la generación siguiente. Desde este punto de vista, Lenta biografía corresponde a lo que Marianne Hirsch, en su ensayo Family Frames. Photography Narrative and Postmemory, define como la "posmemoria", es decir la experiencia de los que crecieron rodeados por los relatos de los sobrevivientes de la segunda guerra mundial. Inducida según Régine Robin por la "transmisión de traumatismos de la guerra o del genocidio por aquellos que no conocieron la guerra o que eran demasiado jóvenes para entender la gravedad de los acontecimientos"', la posmemoria califica un proceso artístico que trata de suscitar la anamnesis mediante el archivo -fotografías, películas, documentos administrativos, relatos orales, etc.- y la imaginación. Cuando el familiar ya no está presente para testimoniar o cuando el dolor del trauma le impide todavía hacerlo, cuando incluso el archivo ha desaparecido, la ficción puede intentar remediarlo paliando los vacíos por el poder de la imaginación. Este proceso posmemorial implica además un cuestionamiento sobre la forma del relato: ¿cómo hacer texto, cómo establecer una continuidad a partir de una "memoria agujereada", según la expresión de Henri Raczymow? ${ }^{4}$ De la misma manera que en los relatos posmemoriales citados por Hirsch, Lenta biografía se caracteriza el rol central de la imaginación en la anamnesis, así como por una elaboración formal que intenta transcribir la errancia de la memoria en la escritura.

El doble choque del genocidio y del exilio "obturó" la memoria del padre puesto que la desaparición de los parientes impide toda tentativa de rememoración:

Él se enteró -quizá la previó- de cierta fractura brutal y compulsiva: sus familiares habían desaparecido -literalmente- del mapa, con lo cual obturaron los recuerdos de ellos en mi padre. Su conciencia, en el momento de enterarse de la tragedia quizá no en el momento de enterarse, quizá no hubo jamás tal momento, sino en el momento de inferirla a partir de los datos transparentes y sombríos de la realidad-, ocluyó seguramente el universo lineal de su memoria y se vio compelido a continuar siempre acompañado de fragmentos o muñones de recuerdos: mientras vadeara el océano y mientras -por siempre- viviera. (Lenta biografía, p. 62-63) 
Es efectivamente una "memoria agujereada" la que hereda el narrador de Lenta biografía, ya que entre los escasos elementos del pasado europeo que su padre acepta brindarle, predomina el silencio. Siempre a punto de hablar o escribir sobre su vida, pero siguiendo finalmente mudo, este prefiere delegar en su hijo la tarea de construir un texto a partir de fragmentos dispersos. Es la intención que vehicula la metáfora de la costura presente al principio del libro, cuando el padre examina con sus hijos un par de zapatos: "mi padre se asomaba -se asoma- a las costuras de los zapatos para que nos asomáramos (aun sin saberlo) a las costuras de sus recuerdos." (19) El hijo intentará así remendar la memoria paterna, aceptando que la anamnesis conlleva una dosis ineludible de fragmentariedad, como lo declara el narrador:

A nosotros [las reuniones] nos aportaban la posibilidad de entrever a partir de los relatos, de las voces, de los gestos y los silencios, esa totalidad que para mí siempre se mantuvo oculta y que fue el pasado de mi padre. Yo lo podía -puedo- reconstruir fragmentariamente; pero nunca tuve la suerte de concebirlo como algo vivo, entero, único y articulado. (110)

Nunca tuve otra cosa que remedos de historias, suposiciones precarias, inferencias inciertas y episodios fragmentarios para ocupar el hueco que significó siempre dentro de mi conciencia y pensamiento el pasado de mi padre; de este modo, ya desde un principio me acostumbré a convivir -no sólo a convivir, sino también a crecer junto a ellas- con aquellas hilachas y acabados jirones de historias y recuerdos. (127)

7 Frente a esa memoria defectuosa, y antes que componer una narración lineal y homogénea, Chejfec elige profundizar las carencias y subrayar las incertidumbres de la memoria. Crea un texto con materiales heterogéneos donde las reflexiones del narrador alternan con algunos recuerdos de infancia pero donde la ficción, asumida como tal, también tiene un lugar central. Dicho rol de la ficción es puesto en evidencia en dos escenas recurrentes: por una parte, la escena de los familiares del padre reunidos en la mesa dominical y por otra parte la escena misma que ellos evocan colectivamente y cuyas distintas versiones confrontan a veces. Se trata de la historia del así llamado "perseguido" -que puede ser tanto el padre del narrador como una proyección del mismo narrador. El narrador describe así a su padre y a los demás exiliados judíos en Buenos Aires tomando copitas de anís y tratando de recordar el pasado europeo. Hablan en idish, lengua de un tiempo y un espacio lejanos, varias veces descrito como un idioma de la "masticación":

Eran reuniones donde él y los demás hablaban en idisch [sic] acerca de sus cosas [...] Eran pedazos de recuerdos, fragmentos, mutilaciones de historias, lo que en esas reuniones se sacaba a la intensa luz [...] Eran labios húmedos, hablando ese idioma tan parecido a la masticación y memorando imágenes evanescentes. [...] Se trataba -se trata-, por ejemplo, de reconstruir vidas de personas lejanas y muertas (23)

\section{Del relato colectivo a la novela solitaria}

Desde el íncipit de Lenta biografía se afirma un corte entre el padre y el hijo: el primero conoce la historia inmemorial de sus antepasados de la comunidades judías de Polonia y considera un deber narrar la historia de todo el linaje desde sus orígenes antes de llegar al relato de su propia vida. El hijo, en cambio, desconoce casi todo sobre el pasado familiar, y busca escribir a partir de estas lagunas, pero su padre no lo obliga a remontar el hilo de los relatos ancestrales para llegar al tiempo presente. Los dos viven en temporalidades distintas: el padre permanece en el tiempo cíclico de los antepasados, del cual está excluido el hijo por la ausencia de transmisión de la memoria familiar y de la cultura 
judía. La generación del padre recrea su historia con relatos del pasado, mientras que la del hijo intenta expresarse con la escritura de la novela.

En su ensayo "El narrador" de 1936 consagrado a Nikolai Leskov, Walter Benjamin constata un agotamiento del arte del relato oral y colectivo que se produce a principios del siglo xx. Concretamente, Benjamin define el fenómeno como una consecuencia de la primera guerra mundial: el cataclismo del conflicto enmudeció a los hombres, que "en lugar de retornar más ricos en experiencias comunicables, volvían empobrecidos" ${ }^{5}$. Con el enmudecimiento de esta experiencia transmisible, el relato empieza a decaer definitivamente, así como el papel del intérprete del fondo narrativo tradicional, la figura del rapsoda que entreteje la experiencia individual y la memoria colectiva. Recordemos que, en la Grecia antigua, el rapsoda es el recitador de poemas épicos pero también, etimológicamente, el que cose o remienda los fragmentos narrativos dispersos.

Es precisamente esta ruptura en la tradición narrativa oral la que presenta Lenta biografía. El deseo inicial que expresa el padre a su hijo es el deseo de conservar una huella no solo de su experiencia individual sino también de la de su comunidad, de no contentarse con una mera autobiografía sino de registrar todas las "historias de vidas" pasadas: "para mí sus deseos en apariencia derivaban, más que de una convicción personal, de una abarcadora difusión de las 'historias de vidas'." (10) Además, el relato colectivo de los judíos exiliados y reunidos alrededor de la mesa del padre corresponde a la concepción benjaminiana del arte antiguo de narrar: implica el cuerpo y se basa en una incesante repetición de las mismas historias. Sin embargo, esta repetición no tiende a una estandarización de la forma o del contenido ya que autoriza variaciones en las sucesivas versiones. Así, en la concepción benjaminiana el arte de narrar se vincula con la artesanía, ya que cada narrador deja su marca personal en la historia que cuenta:

La narración, tal como brota lentamente en el círculo del artesanado -el campesino, el marítimo y, posteriormente también el urbano-, es, de por sí, la forma similarmente artesanal de la comunicación. No se propone transmitir, como lo haría la información o el parte, el "puro" asunto en sí. Más bien lo sumerge en la vida del comunicante, para poder luego recuperarlo. Por lo tanto, la huella del narrador queda adherida a la narración, como las del alfarero a la superficie de su vasija de barro. ${ }^{6}$

11 Chejfec convoca precisamente este universo de la artesanía con la mirada y los ademanes del padre, "zapatero desde niño" (Lenta biografía, p. 17), pero también con la idea de variabilidad de las versiones orales de una misma historia, con el ejemplo de la mujer que en una de las reuniones dominicales reinventa una parte de los hechos: "Me parece que en última instancia la mujer estaba inventando" (108).

Aquí lo que crea el hiato no es la primera guerra mundial sino la segunda, el genocidio y el exilio que acarrea para miles de personas. En eso consiste el trauma que le quita al padre su "facultad de intercambiar experiencias". Los comensales reunidos en la casa familiar aparecen entonces como los últimos representantes del shtetl, de aquella comunidad judía tradicional, nutrida por la memoria colectiva del mundo idish polaco, y en particular por los relatos jasídicos, típicas historias populares que circulaban oralmente, se arraigaban en la vida cotidiana y se prestaban a múltiples reinterpretaciones a lo largo de los siglos. En cambio, el narrador no tiene el conocimiento de ese tipo de relatos tradicionales ni la experiencia de la Shoah o del exilio. En tanto hijo de inmigrante, nacido lejos de Europa y del corazón de la cultura idish, es un mero espectador de un relato colectivo que no lo integra. La novela transmite 
esa experiencia vacante, ese cuestionamiento en cuanto a sus orígenes. Ahora bien, uno de los intereses principales del ensayo de Benjamin consiste justamente en la distinción conceptual entre narración y novela: la primera no puede ser sino oral, la segunda se caracteriza por su "dependencia esencial del libro"; una se elabora colectivamente y a partir de la experiencia mientras que la otra es individual, casi solipsista. Siguiendo la reflexión de Benjamin:

El narrador toma lo que narra de la experiencia; la suya propia o la transmitida, la toma a su vez, en experiencias de aquellos que escuchan su historia. El novelista, por su parte, se ha segregado. La cámara de nacimiento de la novela es el individuo en su soledad; es incapaz de hablar en forma ejemplar sobre sus aspiraciones más importantes; él mismo está desasistido de consejo e imposibilidad de darlo. [...] En medio de la plenitud de la vida, y mediante la representación de esa plenitud la novela informa sobre la profunda carencia de consejo, del desconcierto del hombre viviente. $^{8}$

La primera novela de Chejfec ilustra esta propuesta benjaminiana de una ruptura en la modernidad, de un despedazamiento de la memoria que hasta entonces fundaba la cadena de la tradición, que transmitía de generación en generación los acontecimientos del pasado. Como lo subraya Laurent Demanze, "mientras que la narración se abre hacia la infinitud de las narraciones posibles contenidas por la memoria demencial de los recitadores, la novela se cierra en la última página sin proporcionar el lugar de un diálogo comunitario ni la oportunidad de un relanzamiento narrativo." ${ }^{9}$ Por otra parte, Lenta biografía propone también la lectura de una transmisión cultural judía irrealizada.

\section{Una cultura intransmitida}

14 El hijo parece no haber heredado ningún saber que proceda de esta raigambre judía europea. Cabe subrayar la posición periférica de los dos jóvenes hijos de inmigrantes (el narrador y su hermano de niños) en la mesa donde su padre y los demás exiliados intercambian sus recuerdos: desde cierta distancia observan un mundo que ya no es el suyo y escuchan sin escuchar este ritual "críptico", en esa lengua que les suena tan extraña:

También nosotros -pienso- que desde afuera y los costados de la mesa oíamos y observábamos, con cierta gravedad particular sabíamos regresar a nuestras actividades acostumbradas acompañados de la cobijadora certeza de que el próximo domingo seguiríamos asistiendo -presentes en las reuniones y ausentes en las historias que se contaban-, ansiosamente contagiados por el paciente fervor de los familiares y amigos de mi padre, a los círculos de miradas y palabras que se dibujaban sobre la mesa del comedor y debajo de la araña que pendía del techo. ( Lenta biografía, p. 57, subrayado nuestro)

nos conformábamos, desde los costados de la mesa -desde los costados de ese ritual casero y críptico que es lo que eran (son) esas reuniones-, con suponer (entender y creer) que era probable que aquellas historias hubieran podido suceder. (75, subrayado nuestro)

15 En Lenta biografía, la transmisión de la cultura judía de Europa del este se obtura, no por falta de potenciales herederos, sino porque el hombre apto para legar esta memoria colectiva a sus hijos (el padre del narrador) fue amenazado por el régimen nazi, sufrió la perdida de una gran parte de su familia y fue arrebatado a su mundo familiar, a su tierra y sus costumbres. De esta transmisión quebrada se desprende para el inmigrante de segunda generación una pertenencia a la comunidad judía (y a la diáspora argentina en 
particular) más virtual que real, en la medida en que no será actualizada mediante el culto religioso, la práctica de la lengua o de la tradiciones musicales, culinarias, etc. Se trata entonces de un judaísmo potencial, pero sin contenido.

\section{La disipación de la identidad judía en Los planetas}

En Los planetas es donde destaca más esta idea de una identidad en peligro, a punto de disiparse. Se trata en primer lugar de la identidad y del recuerdo de $\mathrm{M}$ y de los desaparecidos en general, amenazados con borrarse definitivamente, incluso en la memoria de los vivos, por la ausencia de sus nombres en las listas:

no es que fuera preciso verlo en un índice para verificar su paso por la vida, pero ello habría expandido el espesor de su recuerdo; nadie ha vuelto a escribir su nombre ni nadie lo ha leído. ${ }^{10}$

Pero también se trata en Los planetas de la identidad judía de los jóvenes protagonistas: una identidad que, en el cruce de los ámbitos religioso, cultural y lingüístico, está por difuminarse poco a poco, debido a la pérdida de las costumbres y de los ritos en la familia, a la condición diaspórica y la adaptación a los hábitos argentinos.

Es precisamente esta amenaza de una disipación identitaria la que preocupa a $\mathrm{M}$ al principio de la novela cuando, al ver pasar a un grupo de jóvenes judíos ortodoxos, se interroga acerca de lo que constituye la identidad judía de dos muchachos como él y $\mathrm{S}$, que al parecer no practican el judaísmo de manera regular ni hablan el idish cotidianamente. La identidad de los judíos ortodoxos se le antoja a $\mathrm{M}$ como la auténtica y legítima, en la medida en que se inscribe en el tiempo cíclico de la tradición religiosa. Su propia identidad de judíos exiliados de segunda generación, en parte desposeídos de la cultura asquenazí y sin duda poco integrados a la comunidad, le parece, en cambio, más tenue y fragmentaria:

No quiero decir que ellos sean más judíos que otros menos religiosos", continuó M,

"sino que su condición llega hasta hoy con atributos que también hablan de una verdad, y no de una restricción, como en nuestro caso. Nuestra naturaleza está marcada por el abandono, la ausencia, los restos de una plenitud poco a poco más remota y algo exótica: la lengua idisch [sic], las fiestas religiosas, las danzas, la comida; en cambio ellos con cada paso señalan una confirmación [...]. Su vida encuentra en la repetición una virtud, volviéndose perduración. (49-50)

Este tema de la difuminación de la identidad judía en Argentina reaparece al final de la novela, cuando S comenta su impresión, que comparte con M cuando están en la sinagoga, de pertenecer a los últimos representantes de cierta persistencia ritual judaica:

La gente rezaba y la mayoría charlaba, como sucede desde que existen las sinagogas, y con M nos sentíamos representantes finales no de una cultura -ya que en definitiva todo el mundo es último todo el tiempo y todas están siempre a punto de deshacerse-, sino de un tiempo en disolución, con demasiadas dudas para el entusiasmo o la renuncia. (270-271)

A partir de esa falta de transmisión y esta desculturación vinculada con el exilio se puede entender la relación ambivalente del Chejfec lector con la literatura judía, relación distante que evoca en su artículo "Marcas en el laberinto. Literatura judía y territorios". Se trata, como los niños en Lenta biografía, de una mirada "desde los costados de la mesa". La pertenencia de su obra a una supuesta "literatura judía" es tanto más difícil de afirmar cuanto que reintegra en trasfondo algunos temas judíos pero se sitúa en las antípodas de una intención folklorizante. Este problema de inclusión en una cierta categoría literaria 
es, sin embargo, característico de una gran parte de la literatura diaspórica latinoamericana, como lo expresa Dorita Nouhaud en un artículo en que analiza en particular el caso de mujeres mexicanas de origen judío a fines del siglo xx, y obras como Las genealogías de Margo Glantz o La bobe, de Sabina Berman:

¿Se trata de literatura judía en lengua española, o de literatura mexicana sobre temas judíos? ¿Basta a uno con ser judío para que sus escritos pertenezcan a la literatura judía, y hablar de los judíos en una novela hace que esta sea una novela judía? ¿Los autores son mexicanos de origen judío o judíos de nacionalidad mexicana? ${ }^{11}$

\section{La recuperación de un fondo cultural}

21 Si bien una vertiente de la obra de Chejfec expresa una desculturación, también cabe recalcar el proceso literario de recuperación de esta cultura judía (y no solamente asquenazí no transmitida, mediante la integración de ciertas referencias literarias y de ciertos topos judíos. La identidad judía que no ha sido legada por la familia, de manera colectiva y oral, se recuperaría así individualmente y por escrito, mediante la literatura.

Por ejemplo, los relatos jasídicos fueron hipotextos importantes en la composición de Los planetas, como lo menciona Edgardo Berg en su artículo "Paseo, narración y extranjería" ${ }^{2}$. El jasidismo, movimiento de renovación del judaísmo que se fue desarrollando en Europa del Este a partir del siglo xviII, ha dejado como patrimonio literario un conjunto de cuentos y leyendas con objetivos educativos, transmitidos oralmente en idish a través de las generaciones y pese a la diáspora, y luego reunidos por Martin Buber en un volumen publicado poco después de la segunda guerra mundial. Esos relatos breves -a veces solamente unas líneas- escenifican a la grandes figuras bíblicas, a los maestros talmudistas y cabalistas. Al final del siglo XIX, el escritor polaco Isaac L. Peretz reanuda ese folklore literario en idish, en particular con relatos jasídicos escritos u orales y relatos fantásticos cuyos orígenes se remontan a veces hasta el Talmud y en los cuales los personajes principales pueden ser ángeles, rabinos, mártires o pecadores. Esta manipulación del intertexto jasídico por Chejfec es particularmente notable en Los planetas: en el capítulo llamado "Primera historia de M" (historia calificada de "fábula" y cuya narración es suscitada por la visión de los judíos ortodoxos) así como al final del libro con el relato de una obra de teatro idish.

Otra manifestación de reapropiación literaria de un fondo referencial judío es el uso del mito del pueblo errante, mediante el cual el autor parece reapropiarse sus orígenes judíos europeos. Como es sabido, la historia de los judíos está marcada, a partir de la toma de Jerusalén por Tito en el año 70 y la destrucción del Templo, por múltiples expulsiones, en particular hacia varios países de Europa entre los siglos XIII et XV, y por la fragmentación de la comunidad en la diáspora. La historia moderna y contemporánea -desde los pogromos hasta la Shoah- repite, mutatis mutandis, el mito fundador del pueblo perseguido y condenado a la errancia por el desierto del Sinaí. Al motivo del pueblo ambulante, la literatura le opone más a menudo el del hombre solitario que parte a tierras incógnitas en busca de su destino: el mito del judío errante, nacido al principio del siglo XVII, es un ejemplo paradigmático. En la literatura argentina encontramos modelos como el de "El inmortal" de Borges con el personaje de Joseph Cartaphilus o el de Bomarzo de Manuel Mujica Láinez. Sin embargo, en Chejfec la imagen recurrente es el motivo colectivo del pueblo errante. La referencia al relato bíblico del éxodo en Egipto es 
explícita en las dos ficciones autobiográficas que abordan las tradiciones familiares judías: Lenta biografía y Los planetas. En esta última novela, la errancia se presenta como el estado a la vez originario y futuro de la humanidad, y el pueblo judío se muestra asociado a los demás pueblos itinerantes del mundo:

Este tiempo [al cual pertenecen $\mathrm{M}$ y S] era el del pasado viajero de la humanidad y el del futuro viajero de la civilización, según su idea de la sociedad del mañana, como a veces la llamaba. Entre ambos estadios, a la manera de eslabones flotantes, estaban los judíos, los gitanos, los pueblos nómadas de la Amazonia o el Pacífico, las tribus de Mauritania, el Sahara o del África en general. (Los planetas, p. 227)

En Lenta biografía, el exilio del padre del narrador en Argentina aparece como la continuación del destino errante de los antepasados pero también de un pueblo judío mítico desde la huida de Egipto:

La [realidad] que pertenecía a mi padre, que yo debía reconstruir, la ubicaba en el intervalo imaginario que va desde el vadeo judío del mar Rojo encabezado por Moisés hasta su nacimiento en una aldea polaca. [...] Mi padre había terminado recalando en Buenos Aires debido al espanto generalizado que significaba Europa para los judíos como conjunto de personas, y yo entendía que las generaciones anteriores a la suya habían también viajado; si no, no hubieran podido partir de Egipto y llegar, en este caso, a Polonia. (Lenta biografía, p. 15)

Tiempo familiar y tiempo mítico se entrelazan cuando el viaje transatlántico del padre para escapar del nazismo se asimila, en el relato del narrador, a la travesía por el Mar Rojo de los esclavos liberados. Ambos cruces se ciernen como encarnaciones de los innumerables éxodos que componen la historia dolorosa de la diáspora que es también, en cierta medida, parte de la historia familiar de Chejfec. Las dos periplos se confunden así en un acto de fundación que articula elementos del mito nacional y de la novela familiar.

En Los gauchos judíos, Alberto Gerchunoff ya había esbozado un paralelo entre el amanecer del pueblo judío y su historia contemporánea al comparar a los inmigrantes judíos instalados en la pampa al principio del siglo xx con los primeros Hebreos del tiempo bíblico. En Lenta biografía, Egipto, Polonia y Argentina constituyen distintos puntos desde los cuales el narrador teje una historia larga y brutal, tan cíclica como la estructura misma de la novela:

No hay mayor diferencia entre el vadeo judío del mar Rojo y el viaje de mi padre a través del océano para llegar a la Argentina. Entre estos dos éxodos hubo muchos otros, vertiginosos y desconocidos, y a mí me parecía que con la misma brutalidad con que fueron muertos mis tíos y abuelos la casualidad -para decirlo de algún modo- había obrado para que termináramos naciendo en Buenos Aires. (47)

Así, en Lenta biografía los antepasados aparecen como los representantes de este pueblo desplazado que resurgirá luego en Los planetas, a su vez como sinécdoque y parangón de los pueblos errantes del mundo entero. Pero este destino errático no siempre se presenta como la consecuencia de una persecución eterna: la propia identidad judía puede ser la causa de una necesidad de viajar, como es el caso en el cuento "El extranjero", publicado en la revista Punto de Vista en 1993, y en el que la única razón que tiene Ernesto de viajar a otros países no es otra que su origen judío, que lo designa como un nómade por excelencia:

Él decía que era su sangre judía la que lo compelía a viajar, que el origen y la herencia encarnados en su persona lo inducían al nomadismo, a querer estar todo el tiempo retornando a ese extranjero global de donde procedía. ${ }^{13}$ 


\title{
El idish, lengua asíntota
}

28

\author{
pasado su infancia entre el idish de la familia y el castellano practicado en la escuela, y en \\ general fuera de casa:
}

El idish era la lengua que se hablaba en mi casa cuando era chico. La hablaban mis padres entre ellos, y mi abuela, que estaba casi todo el tiempo en la casa. Yo tenía a dos hermanos mayores, y también ellos se comunicaban en idish. Pero yo fui el tercero, y viví en un momento en que poco a poco el castellano se imponía más que el idish en la familia. Entonces el contexto mío fue de escuchar mucho idish todo el tiempo sin entender de qué se estaba hablando. No lo hablé, o si lo hablaba era de manera muy parcial. Después lo aprendí en el colegio, pero es un saber que no mantuve.

El escritor creció, como vemos, en un contexto lingüístico particular: no un bilingüismo estable que hubiese permitido un doble aprendizaje sino una desaparición progresiva de la lengua vernácula y paterna en detrimento del idioma vehicular y escolar. Durante los primeros años del hijo menor, la familia sigue hablando en idish pero a diferencia de los hermanos mayores, al hermano menor ya no le enseñan el idish, que sin embargo la familia seguía hablando. Como consecuencia, la escucha de un idioma a la vez familiar y extranjero, por indescifrable, constituye una situación frecuente de su niñez. Esta etapa se refleja, a su vez, en un progresivo proceso de aculturación lingüística del entorno familiar, que va sustituyendo poco a poco el idioma de la comunidad por el del país de acogida. Chejfec experimenta así la situación, compartida por muchos inmigrantes judíos de segunda generación en América Latina ${ }^{14}$, de una lengua materna (en el sentido de la primera lengua que el niño aprende) que no es la de sus padres, y asimismo un "baño de lenguas" que no entiende: el ruso y el polaco hablados por el padre, y sobre todo el idish, que comprenden todos los demás miembros de la familia.

En Lenta biografía, como ya dijimos, el hijo es quien se encarga de escribir la historia de su padre, escribiendo al mismo tiempo su propia historia en tanto heredero de la "memoria agujereada" de los antepasados y, en un gesto reflexivo, su dificultad de escribir. Chejfec aclara que el deseo original de su padre era escribir en idish, ya que su conocimiento del castellano no era suficiente, y que su hijo luego tradujera el texto:

mi padre me dijo que él querría escribir la historia de su vida; e incluso: que él podía escribirla, por supuesto, en idisch y yo después traducirla u ocuparme de que lo hicieran. Me dijo que no tendría palabras en castellano para "poner" todo lo que tenía por contar. (10)

Sin embargo, Sergio Chejfec elige el castellano para escribir esta biografía parcialmente ficcional: es desde el castellano (y por consiguiente con toda la distancia que implica el hecho de escribir en la lengua del país de llegada antes que en la del país de origen) como Chejfec evoca una memoria familiar que se constituyó en idish, o sea en un idioma del que nunca se apropió. Si consideramos que a través de Lenta biografía Chejfec asume (aunque sea mediante la reinvención) este papel de traductor de la memoria íntima del padre, es interesante subrayar que introduce en su lengua de escritura cierto grado de extrañeza. Ya evocamos antes el valor del idish que hablan los antepasados en la mesa para "imaginar recuerdos": esta lengua que para el narrador es ininteligible, se asemeja a una "masticación". Esta anamnesis obsesiva es propia del discurso de los antepasados, la forma iterativa de la narración misma la restituye. Además, la estructura de los 
fragmentos de la novela dedicados a esta conversación de los exiliados, compuesta como una incesante repetición del mismo recuerdo, con algunas añadiduras y variaciones, hace eco al canto pascal "Had Gadia" aludido en la novela y cuya estructura es la de una canción acumulativa (donde se retoma en cada estrofa todos los versos añadidos a lo largo de las estrofas anteriores).

De alguna manera, Chejfec trata de introducir en la composición de su obra una referencia al idioma original en el que se constituyó la memoria familiar. Este grado de extrañeza (y de extranjería) en el ritmo, hace que el lector perciba el recurso a la lengua castellana por defecto, es decir que detrás del castellano palpita el idish, la lengua olvidada de la infancia y la que mejor convendría a la evocación del pasado europeo. Tal vez sea también esta incomodidad, esta inestabilidad lingüística del narrador que dificulta la escritura del pasado familiar, lo que explica la enunciación vacilante y los procedimientos de autocorrección constante que caracterizan esta primera novela.

A la manera de una curva asíntota en matemáticas, que se aproxima continuamente a una recta sin tocarla nunca, la escritura en castellano de Chejfec trata de acercarse a esa lengua perdida sin poder recuperarla plenamente.

\section{Chejfec - Kafka}

En Últimas noticias de la escritura, Chejfec confiesa que una admiración por Kafka guió sus primeras tentativas de escritura ${ }^{15}$. El autor praguense siguió siendo para él una referencia importante, aunque su impronta se sintiera menos en los libros recientes que en $\mathrm{El}$ llamado de la especie o Los planetas. Son múltiples y reveladores los puntos de comparación entre Kafka y Chejfec en torno a lo judaico. Tanto en Lenta biografía como en la Carta al padre, la relación con el padre proyecta a su vez la relación con los antepasados judíos y con la tradición. Ambos textos revelan una falta de transmisión cultural. El reproche es explícito en Kafka, que lamenta el rechazo y hasta el odio al judaísmo del padre, representante de una generación de judíos emigrados a la ciudad y asimilados a la cultura nacional. Kafka no recibe más que un "simulacro" de judaísmo, un legado "fantasmal"16. El desarraigo del entorno rural bohemio por un lado, y el exilio desde el shtetl polaco a la Argentina por otro: tanto Kafka como Chejfec son hijos de judíos asimilados a una cultura nacional que deja poco espacio para la continuación de las tradiciones judías.

En cuanto a la lengua idish, el entorno, mayoritariamente germanohablante, de la Praga finisecular en el que vive Kafka se caracteriza por un desprecio cada vez más fuerte a un idioma considerado indigno y cada vez más rechazado por los intelectuales judíos. En la época de la juventud de Sergio Chejfec en Argentina, el idish es una lengua que ha desaparecido casi por completo, ya fuera por el genocidio de la mayoría de sus locutores como por la asimilación lingüística progresiva de los sobrevivientes exiliados y de sus hijos.

Un punto en común entre ambos autores es la tentativa de rescate y revalorización literaria del idishkeit (aquí en el sentido de patrimonio asquenazí), tanto con respecto a la lengua tradicional como a cierto fondo narrativo: Kafka también se inspira de los relatos jasídicos, que lo fascinan, y se apasiona por el idish, idioma que descubre de manera tardía mediante una compañía de teatro popular de Praga y que nunca aprenderá realmente, pero sobre el cual pronunciará un discurso famoso en 1912. 


\section{Por una literatura fronteriza} la de los orígenes familiares y la comunidad judía por otro. De un modo parecido al Kafka que se opone en su tiempo al tipo de literatura judía representada por la escuela de Praga, que recurre frecuentemente al repertorio cultural de la tradición judaica, Chejfec rechaza una literatura judía latinoamericana que sea culturalmente exclusiva, y se posiciona más 
bien a favor de lo intercultural. En efecto, en varias ocasiones Chejfec reafirma la relativa distancia que mantiene respecto a la cultura argentina tanto como a la judía, como lo expresa en una entrevista con la imagen de un "borde difuso":

Soy hijo de extranjeros, más aún, de desplazados; he crecido en una familia de inmigrantes, y en un momento advertí la presencia de un contorno en mi propio país. [...] Diría que me sentía cerca de un borde difuso, que mi naturaleza era ajena a cualquiera de las construcciones ideológicas y discursivas de la argentinidad, pero que sin embargo pertenecía a esta comunidad [...]. Entonces llegó un momento en que me fui y encontré que mi lugar pasaba por revivir esa inseguridad desplazándome, porque el desplazamiento era el correlato físico de la brecha temporal que se iba abriendo con mi origen..$^{21}$

Entre la expresión de una pérdida cultural debida a una falta de transmisión por las generaciones anteriores y el intento de recuperar una parte de la identidad judía mediante el recurso a un patrimonio literario judío, la narrativa de Sergio Chejfec traduce una posición cultural e identitaria intermedia: el legado tradicional judío no es plenamente recuperable, pero la asimilación a la cultura nacional queda incompleta ("mi naturaleza era ajena a cualquiera de las construcciones ideológicas y discursivas de la argentinidad").

Finalmente, la trayectoria de Chejfec responde menos a la reivindicación de un origen judío que a la revalorización de una extranjería, tal como lo expresa en su artículo "Lengua simple, nombre" a propósito de la aceptación del apellido paterno judío en tanto nombre extranjero y "blasón excéntrico":

Mi padre pronunciaba "cheifec". Y cuando se trataba de decir el verdadero apellido [...] decía "jeifetz". [...] Ese Jeifetz lo aceptábamos, era el apellido en idish de nuestros nombres en idish; pero que mi padre dijera "cheifec" lo tomábamos como uno más de sus inconvenientes errores de dicción. [...] [D]urante un tiempo demasiado largo rechacé la versión paterna de mi apellido [...], y tiempo después la adopté [...]. Por la época que adopto esta versión de mi padre es cuando me vuelco a escribir; [...] y ahora pienso que me lo permitió precisamente eso, reconocer y adoptar su nombre, o sea, llamarlo como él lo decía, como si fuera un apellido extranjero. [...] [A] través del apellido recuperaba el blasón más excéntrico de mi padre [...] para adoptarlo y naturalizarlo. ${ }^{22}$

\section{BIBLIOGRAFÍA}

Benjamin Walter, El narrador, Madrid, Taurus, 1991.

Chejfec Sergio, Lenta biografía, Buenos Aires, Alfaguara, 2007 [1990].

-- "El extranjero", Punto de Vista, n45, Buenos Aires, abril 1993, p. 6-11.

- Los planetas, Buenos Aires, Alfaguara, 1999.

- "Marcas en el laberinto. Literatura judía y territorios", El punto vacilante. Literatura, ideas y

mundo privado, Buenos Aires, Norma, 2005, p. 119-134.

- "Lengua simple, nombre", El punto vacilante. Literatura, ideas y mundo privado, Buenos Aires :

Norma, 2005, p. 195-205. 
- Últimas noticias de la escritura, Buenos Aires, Entropía, 2015.

Deleuze Gilles, Critique et Clinique, Paris : Minuit, 1993.

Deleuze Gilles \& Guattari Félix, Kafka. Pour une littérature mineure, Paris, Minuit, 1975.

Demanze Laurent, Encres orphelines. Pierre Bergounioux, Gérard Macé, Pierre Michon, Paris, José Corti, 2008.

Ezquerro Milagros (dir.), L'hybride, cultures et littératures hispano-américaines, Paris, Indigo, 2005.

Kafka Franz, Carta al padre y otros escritos, Madrid, Alianza Editorial, 2004.

Munaro Augusto, "La conciencia narrativa. Entrevista a Sergio Chejfec", El ciudadano \& la región, 24 de noviembre 2008.

Raczymov Henry, “La mémoire trouée”, Pardès, Paris, In press, n³, 1986, p. 178.

Robin Régine, Le Deuil de l'origine. Une langue en trop, la langue en moins, Paris, Éditions Kimé, 2003 [1993].

- La Mémoire saturée, Paris, Stock, 2003.

\section{NOTAS}

1. Cita sacada de una entrevista realizada con Sergio Chejfec en París en noviembre 2015.

2. Sergio Chejfec, Lenta biografía, Buenos Aires, Alfaguara, 2007, p. 10.

3. "la transmission de traumatismes de la guerre ou du génocide par ceux qui n'ont pas connu la guerre ou qui étaient trop jeunes pour comprendre la gravité des événements". Régine Robin, La Mémoire saturée, Paris, Stock, 2003.

La traducción es mía.

4. Henry Raczymov, “La mémoire trouée”, Pardès, Paris, In press, n³, 1986, p. 178.

5. Walter Benjamin, El narrador, Madrid, Taurus, 1991, en línea: http://www.periodismo.uchile.cl/ talleres/teoriacomunicacion/archivos/narrador.pdf

6. Walter Benjamin, El narrador, op. cit.

7. Ibid.

8. Ibid.

9. “[t]andis que le récit s'ouvre sur l'infini des récits possibles que porte en elle la mémoire démentielle des récitants, le roman se clôt avec sa dernière page sans fournir le lieu d'une discussion communautaire ou l'occasion d'une relance narrative." Laurent Demanze, Encres orphelines. Pierre Bergounioux, Gérard Macé, Pierre Michon, José Corti, 2008, p. 154. La traducción es mía.

10. Sergio Chejfec, Los planetas, Buenos Aires, Alfaguara, 1999, p. 46.

11. "Sommes-nous en présence de littérature juive en langue espagnole, ou de littérature mexicaine sur des thèmes juifs ? Suffit-il d'être Juif pour que vos écrits appartiennent à la littérature juive, et parler des Juifs dans un roman fait-il de lui un roman juif ? Les auteurs sontils des Mexicains d'origine juive ou des Juifs de nationalité mexicaine ?" Dorita Nouhaud, "Issue de l'émigration, émergence d'une mémoire juive: des romans hybrides, dans la littérature mexicaine à la fin du $\mathrm{xx}^{\mathrm{e}}$ siècle", Milagros Ezquerro (dir.), L'hybride, cultures et littératures hispanoaméricaines, Paris, Indigo, 2005, p. 163. La traducción es mía.

12. Edgardo Horacio Berg, "Paseo, narración y extranjería en Sergio Chejfec", Dianna Niebyslki (dir.), Sergio Chejfec: Trayectorias de una escritura, op. cit., p. 52. Además, Chejfec cita directamente el fragmento de un relato jasídico en su artículo "Marcas en el laberinto" para ilustrar su propósito sobre la literatura judía. Véase Sergio Chejfec, "Marcas en el laberinto. Literatura judía 
y territorios", El punto vacilante. Literatura, ideas y mundo privado, Buenos Aires, Norma, 2005, p. 131.

13. "El extranjero", Punto de Vista, $\mathrm{n}^{\circ} 45$, Buenos Aires, avril 1993, p. 9.

14. La escritora mexicana Margo Glantz, nacida en 1930 de padres judíos ucranianos, describe en una entrevista una situación infantil muy similar a la de Sergio Chejfec, aunque tenga lugar casi treinta años más tarde: “mi lengua materna es el español, que no es la lengua materna de mis padres. Ahí hay una cosa que es curiosa, porque mis padres no me transmitieron su lengua. Yo no aprendí yiddish aunque mi padre era un poeta en yiddish, y no aprendí ruso aunque mi madre, su primera lengua, fue el ruso. [...] En mi caso, mi lengua materna no es la de mis padres, mi lengua materna es la de mi país, que es México." Entrevista publicada en la página web del Instituto de estudios latinoamericanos de la Universidad Libre de Berlín. URL: https://www.lai.fu-berlin.de/ es/e-learning/projekte/frauen_konzepte/projektseiten/frauenbereich/glantz/transcrip/ transcrip_2.html

15. "Hace bastantes años ocupé tardes enteras en copiar relatos de Kafka. Tenía unos cuadernos de tapa blanda color marrón, de formato escolar aunque de pocas páginas. No era escolar sólo el formato: creía que algo de la literatura de ese autor se impregnaría en mí gracias a la transcripción. [...] En un segundo movimiento me puse directamente a escribir cuentos o historias de fuerte inspiración kafkiana, acaso porque pensaba que aquellas sesiones de transcripción habían tenido un efecto benéfico." Sergio Chejfec, Últimas noticias de la escritura, Buenos Aires, Entropía, 2015, p. 22-24.

16. "en la adolescencia, no comprendía cómo tú, con aquel simulacro de judaísmo que poseías, podías hacerme reproches porque yo (aunque sólo fuese por respeto a la tradición, como tú decías) no me esforzaba por practicar un simulacro del mismo género." Franz Kafka, Carta al padre y otros escritos, Madrid, Alianza Editorial, 2004, p. 18.

17. Cabe subrayar que el propio idish se origina en la "alteración" de un idioma ya constituido, ya que consiste en una derivación del alto alemán hibridada lexicalmente con el hebreo y el eslavo, y que se lo puede concebir también como una "lengua menor" que tiene desde siglos una fama inmerecida de alemán "impuro", de jerga popular y oscurantista, de "lengua ilegítima" y de "lengua-paria"...

18. "comme un étranger dans sa propre langue". Gilles Deleuze, Critique et Clinique, Paris, Minuit, "Paradoxe", 1993, p. 138. La traducción es mía.

19. Gilles Deleuze \& Félix Guattari, Kafka. Pour une littérature mineure, Paris, Minuit, coll. "Critique", 1975, p. 34. La traducción es mía.

20. Sergio Chejfec, "Marcas en el laberinto. Literatura judía y territorios", El punto vacilante, op. cit ., p. 125.

21. Augusto MUNARO, "La conciencia narrativa. Entrevista a Sergio Chejfec", El ciudadano \& la región, 24 de noviembre 2008, p. 14-15.

22. Sergio Chejfec, "Lengua simple, nombre", El punto vacilante, op. cit., p. 201.

\section{RESÚMENES}

Si Chejfec narra en su primer libro, Lenta biografía, una transmisión fallida de la memoria familiar y de la cultura asquenazí, también da a leer por otra parte, en particular en Los planetas, la progresiva desaparición de la cultura y las tradiciones judías en la comunidad inmigrante en 
Argentina de la que él procede. Frente a la ausencia de legado, Chejfec busca explorar esta carencia y reapropiarse sus orígenes vía la literatura, recuperando a su manera un patrimonio literario (el topos del pueblo errante, la lengua idish o los relatos jasídicos). No obstante, se opone a una literatura latinoamericana ensimismada y reivindica al contrario una posición literaria fronteriza entre lo judío y la cultura nacional.

Si Chejfec fait dans son premier livre, Lenta biografía, le récit d'une transmission défaillante de la mémoire familiale et de la culture ashkénaze, il donne à lire par ailleurs, dans Los planetas notamment, une progressive disparition de la culture et des traditions juives au sein de la communauté immigrée en Argentine dont il est issu. Face à cet héritage absent, Chejfec cherchera à explorer ce manque et à se réapproprier ses origines via la littérature, en réinvestissant par exemple le topos du peuple errant, la langue yiddish ou les récits hassidiques. Il s'oppose toutefois à une littérature juive latino-américaine fermée sur elle-même pour revendiquer une position littéraire frontalière entre judaïsme et culture nationale.

In his first novel (Lenta Biografia) Chejfec told the story of an unsuccessful transmission of the familial memory and of the Ashquenazi culture. He then dealt with the progressive disappearance of the Jewish traditions and culture within the immigrant community in Argentina from which he comes from (in Los Planetas especially). Confronted to this absence of legacy, Chejfec tried to explore this emptiness and to reclaim his origins via literature, incorporating in his texts the themes of the wandering people, the Yiddish language or the Hassidic stories. However, he is opposed to a Jewish Latin-American literature which would be closed on itself, and claims a literary stance which is between Judaism and national culture.

\section{ÍNDICE}

Mots-clés: identité juive, mémoire familiale, post-mémoire, Kafka, yiddish, assimilation culturelle

Keywords: Jewish identity, familial memory, postmemory, Kafka, Yiddish, cultural assimilation Palabras claves: identidad judía, memoria familiar, posmemoria, Kafka, idish, asimilación cultural

\section{AUTOR}

\section{BENOÎT COQUIL}

Université Paris Est-Créteil

coquilb@gmail.com 